\title{
Aggressiveness of Puccinia striiformis f. sp. tritici Isolates in the South-Central United States
}

\author{
E. A. Milus and E. Seyran, Department of Plant Pathology, and R. McNew, Agriculture Statistics Laboratory, \\ University of Arkansas, Fayetteville 72701
}

\begin{abstract}
Milus, E. A., Seyran, E., and McNew, R. 2006. Aggressiveness of Puccinia striiformis f. sp. tritici isolates in the south-central United States. Plant Dis. 90:847-852.

Although stripe rust, caused by Puccinia striiformis f. sp. tritici, has been an occasional problem on wheat in the south-central United States from 1941 until 1999, the disease has been consistently severe in the region since 2000. Furthermore, since 2000, the geographic range of stripe rust in the eastern United States has expanded, and the old population of races has been replaced by a new population. The objective of this study was to determine whether new isolates of the pathogen were more aggressive and better adapted to warmer temperatures than old isolates. In all, 6 old isolates (collected before 2000) and 14 new isolates (collected since 2000) were evaluated at 12 and $18^{\circ} \mathrm{C}$ for latent period on wheat seedlings and urediniospore germination on Noble agar. At $12^{\circ} \mathrm{C}$, old and new isolates had similar latent periods and spore germination percentages. However, at $18^{\circ} \mathrm{C}$, new isolates averaged 2 days less for latent period and double the spore germination compared with old isolates. Therefore, the new isolates are better adapted and, thus, more aggressive at warmer temperatures than the old isolates. These differences may have contributed to the severity of recent epidemics in the region and to the expanded geographic range for stripe rust.
\end{abstract}

Additional keywords: fitness, yellow rust

Stripe rust, caused by Puccinia striiformis Westend. f. sp. tritici Eriks. \& E. Henn., is one of the most damaging diseases of wheat in many areas around the world, especially in cool environments (26). Stripe rust first was reported in the United States in Arizona in 1915 (3), but later examination of herbarium specimens revealed that the disease had been present for many years earlier (11). As summarized by Line (15), early research on this disease in the United States focused on economic importance, geographic distribution, host range, and cultivar resistance. By the early 1930s, stripe rust had not spread to the wheat-growing regions east of the Rocky Mountains, and its absence from the Great Plains reduced research emphasis on stripe rust. From the early 1930 s to the late $1950 \mathrm{~s}$, there were no major research projects on stripe rust, and only occasional observational reports were published (15).

In the late 1950 s and early 1960 s, severe

Corresponding author: E. A. Milus

E-mail: gmilus@uark.edu

Accepted for publication 11 February 2006.

DOI: 10.1094/PD-90-0847

(C) 2006 The American Phytopathological Society epidemics caused high yield losses in California and the Pacific Northwest (23), and these epidemics led to increased stripe rust research. Since the 1960s, the incidence and virulence of $P$. striiformis f. sp. tritici have been monitored in the United States. Based on geographic barriers, climatic conditions, market classes of wheat, and virulence of races, Line and Qayoum (16) divided the United States into seven epidemiological regions. Region 7 encompassed all states east of the Rocky Mountains.

The first report of stripe rust from region 7 was from central Texas in 1941 (10), and the first widespread epidemics occurred in the Great Plains in 1957 and $1958(8,9)$. Researchers suggested that isolates causing these epidemics may have adapted to warmer temperatures; however, Line (15) found no evidence of this. In the 1960s and 1970s, stripe rust was a sporadic problem east of the Rocky Mountains (15); however, by the early 1980s, stripe rust became increasingly important in the south-central states (Arkansas, Louisiana, and Texas; 16). Only two races, PST- 3 and PST- 8 (formerly CDL-3 and CDL-8), were detected in the region before 1998 (4). In 1998 and 1999, two additional races, PST22 and PST-26 (formerly CDL-22 and CDL-26), were detected in the southcentral states (4).
In 2000, stripe rust occurred in at least 20 states from the Pacific Northwest and California to Virginia and from Texas to North Dakota. This was the most widespread occurrence of stripe rust in the United States and was described in detail by Chen et al. (4). In all, 42 total and 21 new races were identified. Of the 21 new races, 8 races had new combinations of previously known virulence and 13 races were virulent to one or more of the differential lines and yellow rust $(Y r)$ genes: Avocet isoline $\operatorname{Yr} 8$, Avocet isoline $\operatorname{Yr} 9$, Clement $(Y r 9+)$, and Compair ( $Y r 8+)$. This was the first report of virulence to $\operatorname{Yr} 8$ and $\operatorname{Yr} 9$ in the United States. Most of the new races also were virulent on Express, a spring wheat grown in California with undescribed resistance to stripe rust (4). Before 2000, all new races were found first in the Pacific Northwest or California; however, in 2000, 13 new races were identified east of the Rocky Mountains. The epidemics in 2000 were attributed to a combination of favorable weather and the presence of new races of the pathogen (4), although no weather data were presented.

It is possible that factors other than favorable weather and new virulence and virulence combinations may have contributed to the unusually severe and widespread stripe rust epidemics in region 7 during the 2000 to 2005 seasons. E. A. Milus and R. McNew (unpublished data) used two-group $T$ tests to compare monthly average temperature and precipitation for the 6 years before the 2000 epidemic (September 1993 to August 1999) and after it (September 1999 to August 2005) for five cities (Baton Rouge, LA; Dallas, TX; San Antonio, TX; Little Rock, AR; and Oklahoma City, OK) in the southcentral United States. Of the 60 paired comparisons (five cities $\times 12$ months) for each variable, only precipitation during January at Baton Rouge was significantly different $(P \leq 0.05)$ for the before and after periods, suggesting that favorable weather was not a major factor for the severe epidemics since 2000. Of the new virulences ( $Y r 8,9$, and Express) that were first identified in region 7 during 2000, only virulence to $\operatorname{Yr} 9$ likely played any role in the epidemics because resistance gene $\operatorname{Yr} 8$ and the resistance in Express are not known to be in cultivars grown in the region. 
Beginning in 2000, observations made throughout region 7 revealed that stripe rust continued to develop long after temperatures were presumed to be too high for disease development, was more severe than in years before 2000, and developed year after year in areas that had never recorded stripe rust before 2000 (2). Data from the 2000 to 2004 national stripe rust race surveys (Xianming Chen, personal communication) indicated that the races that had been found in region 7 before 2000 (PST-3, PST-8, PST-22, and PST-26) were no longer found and that races that first were identified in 2000 or later had completely replaced the previous population. These data and observations suggested that the new races might be more

Spore production, latent period (time from inoculation to sporulation), spore germination rate, and infection efficiency have been regarded as components of aggressiveness for $P$. striiformis f. sp. tritici $(21,26)$, but there are few publications that demonstrate differences in aggressiveness among isolates. Priestly and Doling (20) documented significant differences in aggressiveness among four isolates of the same race using the length of pustules after point inoculation of wheat leaves (a variable positively correlated with the amount of spore production but easier to measure). Line and Qayoum (16) reported that races virulent only on the differential line Chinese 166 had longer latent periods and produced fewer spores than other races. aggressive than the old races.

Aggressiveness of an isolate may depend on the host and environment (1). Rapilly (21) stated that temperature has the greatest effect on aggressiveness as measured by latent period and sporulation. Volin and Sharp (25) concluded that two races were more aggressive than eight other races because they had significantly higher percentages of urediniospore germination at 5 , 10,15 , and $20^{\circ} \mathrm{C}$. Results at $20^{\circ} \mathrm{C}$ were especially interesting because $25 \%$ of the spores of the aggressive races germinated, whereas none of the spores of the other races germinated.

The objective of this study was to determine whether isolates of $P$. striiformis $\mathrm{f}$. sp. tritici collected since 2000 were more aggressive and more adapted to warmer temperatures than isolates collected before 2000. Two preliminary reports have been published $(18,22)$.

\section{MATERIALS AND METHODS}

Pathogen isolates. Twenty isolates of $P$. striiformis f. sp. tritici (Table 1) were used in latent period and spore germination experiments. Six isolates collected before 2000 were considered "old," and these included all known viable isolates (AR9001-SP, AR97-01-SP, CDL-3-2-SP, and CDL-8-3-SP) that were collected from region 7 before 2000. Fourteen isolates collected in 2000 or later were considered "new," and these included isolates $(2 \mathrm{~K}$ 127-SP, 2K-129-SP, 01-69, and 01-118) provided by Dr. Xianming Chen (United States Department of Agriculture-

Table 1. Isolates of Puccinia striiformis f. sp. tritici used in this study, their race designation, origin, year of collection, and testing group

\begin{tabular}{llllc}
\hline Isolate & Race & Origin & Year & $\begin{array}{c}\text { Testing } \\
\text { group }^{\mathbf{z}}\end{array}$ \\
\hline AR90-01-SP & PST-3 & Arkansas & 1990 & 1 \\
2K-129-SP* & PST-59 & Oklahoma & 2000 & 1 \\
$01-69^{*}$ & PST-78 & Kansas & 2001 & 1 \\
01-118* & PST-77 & Kansas & 2001 & 1 \\
2K-127-SP* & PST-60 & Alabama & 2000 & 1 \\
CDL-8-3-SP* & PST-8 & Arkansas & Before 2000 & 2 \\
AR00-02-SP1 & PST-78 & Arkansas & 2000 & 2 \\
AR00-05-SP1 & PST-78 & Arkansas & 2000 & 2 \\
AR03-17-SPF & PST-100 & Arkansas & 2003 & 2 \\
AR03-31-SPF & PST-100 & Arkansas & 2003 & 2 \\
AR97-01-SP & PST-3 & Arkansas & 1998 & 3 \\
AR03-25-SPF & PST-100 & Arkansas & 2003 & 3 \\
AR03-04-SPF & PST-100 & Arkansas & 2003 & 3 \\
CDL-3-2-SP* & PST-3 & Arkansas & Before 2000 & 3 \\
AR03-33-SPF & PST-100 & Arkansas & 2003 & 3 \\
CDL-6-3* & PST-6 & California & 1974 & 4 \\
CDL-35-3* & PST-35 & California & 1985 & 4 \\
AR03-17-SPF & PST-100 & Arkansas & 2003 & 4 \\
AR03-01-SPF & PST-100 & Arkansas & 2003 & 4 \\
AR03-14-SPF & PST-100 & Arkansas & 2003 & 4 \\
\hline
\end{tabular}

"Isolates in bold were collected before 2000 and considered "old"; others were collected since 2000 and considered "new". Isolates footnoted with an asterisk (*) were provided by X. M. Chen, United States Department of Agriculture, Agricultural Research Service, Pullman, WA; others were collected by the wheat pathology program at the University of Arkansas. SP = single-pustule isolate from bulk collection; SPF = single-pustule isolate from a leaf in the field that was incubated on benzimidazole agar; other isolates were not derived from a single pustule; AR03-17-SPF was used in two testing groups.

y As described by Chen et al. (4).

${ }^{\mathrm{z}}$ Isolates within a testing group were tested at the same time.
Agricultural Research Service, Pullman, WA) as representative of the pathogen population from region 7 in 2000 and 2001.

All isolates had been stored at $-80^{\circ} \mathrm{C}$ for various time periods before the beginning of this study. To standardize the physiological conditions of the urediniospores, fresh urediniospores were produced from these stored isolates under similar conditions. Due to limited growth chamber space for producing urediniospores with minimal cross-contamination, five isolates were tested at a time and were considered a testing group. Urediniospores were increased on wheat seedlings of cvs. Florida 302 and Agripro Hickory that were grown in $8-\mathrm{cm}$ pots filled with potting mix (six parts peat moss, four parts vermiculite, two parts perlite, three parts Roxana silt loam soil, and three parts sand). Seedlings were fertilized with Peters 20-20-20 NPK fertilizer at the rate of $1 \mathrm{~g} /$ liter after emergence and before inoculation. When the second leaf was 2 to $3 \mathrm{~cm}$ long, seedlings were treated with $20 \mathrm{ml}$ of $0.33 \%$ maleic hydrazide solution per pot to prevent further leaf formation and enhance sporulation. When primary leaves were fully expanded, seedlings were inoculated with urediniospores suspended in Soltrol 170 mineral oil (Chevron-Phillips Chemical Co., Houston, TX). After the oil evaporated, inoculated seedlings were placed in a dark dew chamber at $12^{\circ} \mathrm{C}$ for $18 \mathrm{~h}$. After the dew period, seedlings were incubated in growth chambers at 15 and $10^{\circ} \mathrm{C}$ (day and night) and a 16-h photoperiod. Urediniospores were collected using a vacuum spore collector 14 to 28 days after inoculation, dried in a desiccator at $5^{\circ} \mathrm{C}$ for $24 \mathrm{~h}$, and used in the latent period and spore germination experiments.

Latent period. Isolates were evaluated for latent period on the soft red winter wheat cvs. FFR 522, FFR 510, Sisson, Pioneer variety 2684, and Agripro Hickory that were selected based on high levels of susceptibility in the field. Two seeds of each cultivar were planted in 8-cm pots filled with potting mix, and emerging seedlings were thinned to one per cultivar. When primary leaves were fully expanded, seedlings from six pots per isolate were inoculated with $0.8 \mathrm{mg}$ of urediniospores in $1 \mathrm{ml}$ of Soltrol 170. After incubation in a dark dew chamber at $12^{\circ} \mathrm{C}$ for $18 \mathrm{~h}$, three pots per isolate were placed in growth chambers at a constant 12 and $18^{\circ} \mathrm{C}$, with a 16-h photoperiod. Isolates in each testing group were evaluated twice. These temperatures were chosen because $12^{\circ} \mathrm{C}$ is in the optimal range of temperatures and $18^{\circ} \mathrm{C}$ is near the maximum temperature for stripe rust development (5).

To determine the latent period, the primary leaf of each seedling was examined using a hand lens at 12-h intervals beginning 8 days after inoculation, and the time in days from inoculation to first sporula- 
tion was recorded as the latent period. Seedlings on which sporulation did not occur by 16 days after inoculation likely escaped infection, and the latent period was recorded as a missing value.

Spore germination. A small aliquot of urediniospores of each isolate, produced as described above, and two drops of deionized water were spread on 1-day-old $1.5 \%$ Noble agar (6) in six plastic petri dishes. Three petri dishes were placed in growth chambers at 12 or $18^{\circ} \mathrm{C}$ and continuous photoperiod (approximately 77,500 lux). At 3, 6, and $12 \mathrm{~h}$ after spores were applied to the agar, approximately one-third of the agar from each dish was excised and placed on a microscope slide, and 100 spores were examined for germination at $\times 500$ magnification. Urediniospores were considered germinated when the length of the germ tube was equal to the diameter of the spore (26). Each isolate was evaluated in two experiments. Spore germination data were expressed as two response variables. Germination at $12 \mathrm{~h}$ represented the final germination success. Area under the germination curve (AUGC) between 0 and $12 \mathrm{~h}$ integrated germination rate and final germination into a single variable.

Statistical analyses. Data for latent period, AUGC, and germination percentage at $12 \mathrm{~h}$ (transformed using the arcsinesquare root transformation) were analyzed using the MIXED procedure of SAS statistical software (version 8; SAS Institute Inc., Cary, NC). Effects in the linear model were constructed from the random factors of test (i.e., repetition) and pot, which provided the replication, and the fixed effects of temperature, isolate, and cultivar. Effects constructed from cultivar and pot were used only in the analysis of latent period. The fixed effects in the model were the main effects and the interaction effects of the fixed factors. The random effects were those of test nested within temperature, test $\times$ isolate nested within temperature, pot nested within each temperature $x$ test $\times$ isolate combination, and test $\times$ cultivar nested within each temperature $x$ test $x$ isolate combination. The residual was that due to seedlings and petri dishes in the analysis of latent period and spore germination, respectively. Contrasts were used to compare the old and new isolates and to assess the interaction of this comparison with temperature. Pairwise comparisons of least squares means were done using the LSMEANS and ESTIMATE statements with no adjustment of $P$ values for multiple testing.

\section{RESULTS}

Latent period. There were significant $(P<0.05)$ temperature $\times$ isolate, temperature $\times$ cultivar, and isolate $\times$ cultivar interactions for latent period (Table 2). The temperature $\times$ cultivar interaction was not relevant to the evaluation of isolates and was ignored. The nonsignificant tempera- ture $x$ isolate $x$ cultivar effect suggested that minor variations in the data may have caused the isolate $\times$ cultivar effect to be significant $(P=0.025)$. Examination of least square means output for the temperature $x$ isolate $\times$ cultivar effect revealed that only three isolates did not act consistently on all five of the cultivars (Table 3). For isolates 2K-127-SP and AR03-14-SPF, estimates of the isolate $\times$ cultivar effect on each of the five cultivars were positive, cally shorter at 18 than at $12^{\circ} \mathrm{C}$. On three of the five cultivars, these two isolates had significantly shorter latent periods at 18 than at $12^{\circ} \mathrm{C}$. For isolate CDL-6-3, estimates of the isolate $\times$ cultivar effect on each of the five cultivars were negative, indicating that latent periods were numerically shorter at 12 than at $18^{\circ} \mathrm{C}$. On one of five cultivars, isolate CDL-6-3 had a significantly shorter latent period at 12 than at $18^{\circ} \mathrm{C}$. Therefore, the statistically significant isolate $\times$ cultivar effect was caused by differences in the magnitude and not the direction of the latent period response and likely had little effect on the results.

Comparisons of latent periods for 20 isolates at 12 and $18^{\circ} \mathrm{C}$ (Table 4) indicated that all 14 new isolates had significantly shorter latent periods at 18 than at $12^{\circ} \mathrm{C}$. indicating that latent periods were numeri-

Of the six old isolates evaluated, four had similar latent periods at both temperatures, isolate CDL-3-2-SP had a significantly shorter latent period at $18^{\circ} \mathrm{C}$, and isolate AR97-01-SP had a significantly shorter latent period at $12^{\circ} \mathrm{C}$. Isolate AR00-05-SP1 sporulated almost 4 days sooner at 18 than at $12^{\circ} \mathrm{C}$. Isolate AR03-17-SPF was used in two testing groups and had very similar latent periods at each temperature, further indicating that the results were repeatable.

Spore germination. There was a significant temperature $x$ isolate interaction for both percentage of urediniospores germinated at $12 \mathrm{~h}$ and AUGC (Table 5), indicating that at least some isolates responded differently at the two temperatures. For AUGC, eight new isolates and one old isolate had significantly higher values at 18 than at $12^{\circ} \mathrm{C}$, and two old isolates had significantly higher values at 12 than at $18^{\circ} \mathrm{C}$ (Table 6). For the percentage of urediniospores germinated at $12 \mathrm{~h}$, seven new isolates and two old isolates had significantly higher germination rates at 18 than at $12^{\circ} \mathrm{C}$, and two old isolates and one new isolate had significantly higher germination rates at 12 than at $18^{\circ} \mathrm{C}$ (Table 6). Five new isolates (AR03-17-SPF, 2K-127-SP, AR00-02-SP1, and AR00-05-SP1, and 2K129) and one old isolate (AR90-01-SP)

Table 2. Statistical tests for the main effects and interactions of temperature, isolate, and cultivar on latent period and for contrasts involving new versus old isolates

\begin{tabular}{lrrr}
\hline Effects and interactions & DF & $\boldsymbol{F}$ value & $\boldsymbol{P}$ value \\
\hline Temperature & 1 & 183.40 & $<0.001$ \\
Isolate & 19 & 24.98 & $<0.001$ \\
New versus old & 1 & 164.07 & $<0.001$ \\
Temperature $\times$ isolate & 19 & 9.42 & $<0.001$ \\
Temperature $\times$ new versus old & 1 & 97.86 & $<0.001$ \\
Cultivar & 4 & 2.48 & 0.046 \\
Temperature $\times$ cultivar & 4 & 2.98 & 0.021 \\
Isolate $\times$ cultivar & 76 & 1.46 & 0.025 \\
New versus old $\times$ cultivar & 4 & 1.77 & 0.137 \\
Temperature $\times$ isolate $\times$ cultivar & 76 & 1.34 & 0.062 \\
Temperature $\times$ new versus old $\times$ cultivar & 4 & 0.79 & 0.062 \\
\hline
\end{tabular}

Table 3. Mean square estimates and probabilities for the isolate $\times$ cultivar effects on latent period for the three isolates that did not respond similarly on all five cultivars

\begin{tabular}{|c|c|c|c|}
\hline Isolate & Cultivar & Estimate $^{\mathrm{y}}$ & Probability $>t^{\mathrm{z}}$ \\
\hline \multirow[t]{5}{*}{$2 \mathrm{~K}-127-\mathrm{SP}$} & FFR 522 & 1.1667 & $0.0047 *$ \\
\hline & FFR 510 & 1.0833 & $0.0082 *$ \\
\hline & Sisson & 0.6667 & 0.0955 \\
\hline & Pioneer 2684 & 0.5000 & 0.2080 \\
\hline & Agripro Hickory & 0.8333 & $0.0389 *$ \\
\hline \multirow[t]{5}{*}{ AR03-14-SPF } & FFR 522 & 0.9167 & $0.0238 *$ \\
\hline & FFR 510 & 0.6374 & 0.1222 \\
\hline & Sisson & 1.0695 & $0.0155^{*}$ \\
\hline & Pioneer 2684 & 1.0261 & $0.0138 *$ \\
\hline & Agripro Hickory & 0.8153 & 0.0503 \\
\hline \multirow[t]{5}{*}{ CDL-6-3 } & FFR 522 & -0.6476 & 0.1112 \\
\hline & FFR 510 & -1.1727 & $0.0047^{*}$ \\
\hline & Sisson & -0.8016 & 0.0566 \\
\hline & Pioneer 2684 & -0.1948 & 0.6276 \\
\hline & Agripro Hickory & -0.5833 & 0.1432 \\
\hline
\end{tabular}

${ }^{y}$ Positive estimates indicate that the latent period on this cultivar was shorter at $18^{\circ} \mathrm{C}$ than at $12^{\circ} \mathrm{C}$. Negative estimates indicate that the latent period on this cultivar was shorter at $12^{\circ} \mathrm{C}$ than at $18^{\circ} \mathrm{C}$.

${ }^{\mathrm{z}}$ An asterisk (*) indicates that isolate had a significantly $(P \leq 0.05)$ shorter latent period at either $12^{\circ} \mathrm{C}$ or $18^{\circ} \mathrm{C}$ depending on the sign of the estimate. 
had significantly higher values for both lates (CDL-3-2-SP and CDL-6-3) had significantly higher values for both variables at 12 than at $18^{\circ} \mathrm{C}$. When isolate AR03-17-SPF was used in two testing groups, similar germination rates were obtained for both variables, further indicating that these results were repeatable.

Five isolates (01-118, 01-69, CDL-8-3SP, AR03-33-SPF, and AR03-01-SPF) had tures for one of the germination variables but not the other (Table 6). When final germination percentages were similarly high at both temperatures (e.g., isolates 01118 and 01-69), a significant difference was detected using AUGC because the germination rate was faster at $18^{\circ} \mathrm{C}$. When AUGC values were similarly low (e.g., isolates CDL-8-3-SP, AR03-33-SPF, and AR03-01SPF), a significant difference was detected by germination at $12 \mathrm{~h}$ because most of the spores germinated between 6 and $12 \mathrm{~h}$, and this had less impact on AUGC than on the percentage germinated at $12 \mathrm{~h}$.

Comparing old versus new isolates. Based on significant temperature $\times$ new variables at 18 than at $12^{\circ} \mathrm{C}$. Two old isosignificant differences between tempera-

versus old comparisons for latent period (Table 2) and urediniospore germination at $12 \mathrm{~h}$ and AUGC (Table 5), these interaction means were compared using pairwise $t$ tests (Table 7). At $12^{\circ} \mathrm{C}$, old and new isolates were similar for latent period, spore germination at $12 \mathrm{~h}$, and AUGC. However, at $18^{\circ} \mathrm{C}$, new isolates had shorter latent periods, greater spore germination at $12 \mathrm{~h}$, and greater AUGC values than old isolates. On average, new isolates sporulated 2 days sooner and had double the germination percentage of old isolates at $18^{\circ} \mathrm{C}$.

\section{DISCUSSION}

The results of this study indicated that new isolates of $P$. striiformis $\mathrm{f}$. sp. tritici had shorter latent periods and greater urediniospore germination at 18 than at $12^{\circ} \mathrm{C}$. Old isolates had latent periods and germination rates that were similar at both 12 and $18^{\circ} \mathrm{C}$ and similar to those of the new isolates at $12^{\circ} \mathrm{C}$. Therefore, the new isolates are better adapted and more aggressive at warmer temperatures than old isolates.

Furthermore, old isolates, represented by races PST- 3 and PST- 8 that had been

Table 4. Latent period of Puccinia striiformis f. sp. tritici isolates averaged across five wheat cultivars at 12 and $18^{\circ} \mathrm{C}$ and ranked by the difference between latent periods at 12 and $18^{\circ} \mathrm{C}$

\begin{tabular}{lccc}
\hline & & \multicolumn{2}{c}{ Latent period (days) $^{\mathbf{z}}$} \\
\cline { 3 - 4 } Isolate $^{\mathbf{y}}$ & Testing group & $\mathbf{1 2}^{\circ} \mathbf{C}$ & $\mathbf{1 8}^{\circ} \mathbf{C}$ \\
\hline AR00-05-SP1 & 2 & 13.0 & $9.1^{*}$ \\
AR03-33-SPF & 3 & 12.4 & $10.1^{*}$ \\
AR03-25-SPF & 3 & 12.0 & $9.7^{*}$ \\
01-69 & 1 & 11.1 & $9.1^{*}$ \\
2K-129-SP & 1 & 11.5 & $9.7^{*}$ \\
AR03-04-SPF & 3 & 12.7 & $11.0^{*}$ \\
01-118 & 1 & 10.6 & $9.1^{*}$ \\
AR03-31-SPF & 2 & 12.9 & $11.5^{*}$ \\
AR03-17-SPF & 4 & 10.8 & $9.5^{*}$ \\
AR03-17-SPF & 2 & 11.2 & $10.0^{*}$ \\
AR00-02-SP1 & 2 & 11.0 & $9.9^{*}$ \\
AR03-01-SPF & 4 & 10.9 & $9.8^{*}$ \\
AR03-14-SPF & 4 & 10.1 & $9.2^{*}$ \\
2K-127-SP & 1 & 11.1 & $10.2^{*}$ \\
CDL-3-2-SP & 3 & 10.8 & $10.0^{*}$ \\
AR90-01-SP & 1 & 11.7 & 11.4 \\
CDL-8-3-SP & 2 & 12.3 & 12.0 \\
CDL-35-3 & 4 & 12.5 & 12.7 \\
CDL-6-3 & 4 & 12.4 & 13.1 \\
AR97-01-SP & 3 & $11.0^{*}$ & 12.0 \\
\hline
\end{tabular}

${ }^{\mathrm{y}}$ Isolates in bold were collected before 2000 and considered "old" and all others were collected since 2000 and considered "new."

${ }^{\mathrm{z}}$ An asterisk $(*)$ indicates that latent period within a row was significantly shorter $(P \leq 0.05)$ than the latent period at the other temperature by a contrast between the two means.

Table 5. Analysis of variance table for percentage of urediniospores germinated after $12 \mathrm{~h}$ and area under the germination curve (AUGC)

\begin{tabular}{lrrrrrr}
\hline & & \multicolumn{2}{c}{ Germination at $\mathbf{1 2} \mathbf{~ h}(\boldsymbol{\%})^{\mathbf{y}}$} & & \multicolumn{2}{c}{ AUGC $^{\mathbf{z}}$} \\
Source & DF & $\boldsymbol{F}$ value & Prob $>\boldsymbol{F}$ & & $\boldsymbol{F}$ value & Prob $>\boldsymbol{F}$ \\
\hline Temperature & 1 & 40.81 & 0.002 & & 105.43 & $<0.001$ \\
Isolate & 19 & 62.65 & $<0.001$ & & 128.62 & $<0.001$ \\
New versus old & 1 & 29.67 & $<0.001$ & & 91.99 & $<0.001$ \\
Temperature $\times$ isolate & 19 & 9.56 & $<0.001$ & & 20.97 & $<0.001$ \\
Temperature $\times$ new versus old & 1 & 32.49 & $<0.001$ & & 53.90 & $<0.001$ \\
\hline
\end{tabular}

${ }^{y}$ Germination based on analysis of arcsine-transformed data; Prob = probability.

${ }^{\mathrm{z}}$ AUGC based on data recorded at 3,6, and $12 \mathrm{~h}$. present for many years before $2000(4,16)$ and races PST-22 and PST-26 that were found from 1997 through 1999 (4) in states east of the Rocky Mountains, were not found in this region since 2000 (4; U.S. Stripe Rust Survey results 2001 to 2004, X. M. Chen, personal communication). Since 2000, new isolates of the stripe rust fungus have been a yearly threat to winter wheat production in the southern Great Plains and the lower Mississippi River Valley, and they have appeared consistently in several northern and eastern states that first reported stripe rust in $2000(2,4)$. This sudden and complete replacement of old isolates by new isolates across an expanded geographic range indicates that new isolates have greater fitness than old isolates.

Latent periods in this study ranged from 9.1 to 13.1 days depending on the isolate and temperature. The shortest latent period reported by Zadoks (26) was 11 days, but the experiment was conducted in the field on plants beyond the seedling stage, and a hand lens was not used to determine when spores first became visible, as was done in the current study. The effect of short latent period on rust disease development was demonstrated by Lehman and Shaner (14), who used a simulation model to predict wheat leaf rust severity on resistant and susceptible cultivars. Latent periods for several isolates of $P$. triticina were measured on each cultivar and were categorized as long, intermediate, or short. On average, isolates with short latent periods were predicted to cause 2.5 times more disease during a typical season. Differences of this magnitude would be very significant in the field.

New isolates tended to have faster spore germination rates than old isolates at $18^{\circ} \mathrm{C}$; however, germination rates varied greatly among isolates for both AUGC (5 to 1,006) and percentage germinated at $12 \mathrm{~h}(<1$ to $100 \%)$. AUGC appeared to be a better measure of germination rate than the percentage germinated at $12 \mathrm{~h}$ because it integrated data from observations at 3,6, and $12 \mathrm{~h}$ into one variable, and quick germination (e.g., at $3 \mathrm{~h}$ ) was weighted more heavily than slower germination (e.g., at $12 \mathrm{~h}$ ). Under field conditions, isolates with quick germination would be favored because there would be a greater number of short periods than long periods that were favorable for germination. Also, isolates able to germinate at warmer temperatures would allow disease development later in the season.

The results of this study were similar to those of Volin and Sharp (25), who reported that two races of $P$. striiformis $\mathrm{f}$. $\mathrm{sp}$. tritici had higher percentages of spore germination than eight other races at 5, 10, and $15^{\circ} \mathrm{C}$ and that the same two races were the only races able to germinate at $20^{\circ} \mathrm{C}$. They concluded that these two races were more aggressive than the other races be- 
cause a greater percentage of spores germinated across a broader temperature range, and they hypothesized that this difference would confer a selective advantage in the field. However, these two races were virulent on Chinese 166, and Line and Qayoum (16) reported that races with virulence on Chinese 166 were less aggressive than other races and never predominated in wheat fields or inoculated plots. Apparently, germination ability is controlled by different genes than latent period and spore production, and germination ability is a poor predictor of competitiveness in the field.

Manners (17) reported that several factors contributed to high variability in experiments designed to measure urediniospore germination rates of $P$. striiformis $\mathrm{f}$. sp. tritici. These factors included the time of year that spores were produced, the level of spore hydration, the type of agar medium, and the spore density on the medium. Although the methods used in this study attempted to standardize the agar medium and the physiological condition of urediniospores, it was likely that some of the factors reported by Manners affected the results. Spores of the isolates were produced and tested in groups of five over a period of about a year. Also, the large differences in germination rate among isolates (e.g., $<1$ to $100 \%$ germination at $12 \mathrm{~h}$ ) were unlikely due to genetic effects. Because of these difficulties and the association of high germination with poor competitiveness in the field, urediniospore germination does not appear to be one of the most useful variables for measuring aggressiveness of $P$. striiformis $\mathrm{f}$. $\mathrm{sp}$. tritici.

Spore production appears to be a good variable for measuring aggressiveness of cereal rust fungi. Isolates capable of producing more spores than other isolates likely would have an advantage. In this study, differences among the isolates in sporulation capacity were observed visually but were not measured quantitatively. Isolates that had short latent periods (e.g., AR00-05-SPF) appeared to produce more spores. Zadoks (26), described sporulation as a key factor of stripe rust epidemiology. Rapilly (21) reported that sporulation is the main component of aggressiveness of $P$. striiformis. Johnson and Taylor (12) demonstrated significant differences in spore production rate among isolates of the same $P$. striiformis race. They concluded that genetic differences among the isolates caused differences in spore production, and isolates with high spore production capacity would have higher epidemic development rate (aggressiveness). Future studies on the aggressiveness of this fungus should include a measure of spore production.

The results of this study explain why stripe rust has become a major wheat disease in the south-central United States. The increased aggressiveness, adaptation, and fitness of the new isolates have significant implications for effective management of stripe rust in states east of the Rocky Mountains. Although resistance to stripe rust had not been a priority before 2000 , stripe rust resistance should be incorporated into hard red winter and soft red winter wheat cultivars because it appears that stripe rust will continue to be a problem in this region. Isolates used to screen breeding lines for resistance should be selected for high aggressiveness in addition to wide virulence. Given that a maximum of one foliar fungicide application is used on wheat for economic reasons, recommendations for the use and timing of a single fungicide application to manage wheat diseases should be revised to counter the effects of aggressive races. For example, before 2000, a fungicide application was not likely to be made for stripe rust in the south-central United States because disease progress usually slowed and eventually stopped before causing losses. However, since the new isolates appeared in 2000, stripe rust increases faster and continues longer, thereby requiring a fungicide application to prevent losses on susceptible cultivars. Furthermore, fungicides are more efficacious when applied before upper leaves become infected; therefore, the application should be made while the level of disease is still low.

$\mathrm{Cv}$. Sisson that was used in this study has resistance gene $\operatorname{Yr} 9$ and is classified as resistant to old isolates that lack virulence for $\operatorname{Yr} 9$ (E. A. Milus, unpublished data). However, the presence of $Y r 9$ in Sisson did not lengthen the latent period of old isolates relative to latent periods on cultivars without $\operatorname{Yr} 9$. E. A. Milus (unpublished data) noted that the infection types produced on seedlings of several soft red winter wheat lines known to have $\operatorname{Yr} 9$ were higher (infection types 2 to 4 on a 0 -to-9 scale; 16) compared with the Avocet Yr9 isoline (infection type 1). These unexpected results may indicate that Sisson and other lines with $\operatorname{Yr} 9$ have one or more modifier genes that condition an infection

Table 6. Urediniospore germination of Puccinia striiformis f. sp. tritici isolates at 12 and $18^{\circ} \mathrm{C}$ expressed as area under the germination curve (AUGC), and percentage germinated after $12 \mathrm{~h}$ and ranked by the difference between $\mathrm{AUGC}$ at 18 and $12^{\circ} \mathrm{C}^{\mathrm{w}}$

\begin{tabular}{|c|c|c|c|c|c|}
\hline \multirow[b]{2}{*}{ Isolate $^{\mathrm{z}}$} & \multirow[b]{2}{*}{ Testing group } & \multicolumn{2}{|c|}{ AUGC ${ }^{x}$} & \multicolumn{2}{|c|}{ Germination at $12 \mathrm{~h}(\%)$} \\
\hline & & $12^{\circ} \mathrm{C}$ & $18^{\circ} \mathrm{C}$ & $12^{\circ} \mathrm{C}$ & $18^{\circ} \mathrm{C}$ \\
\hline AR03-17-SPF & 2 & 146 & $745^{*}$ & 26 & $96^{*}$ \\
\hline 2K-127-SP & 1 & 104 & $466^{*}$ & 20 & $69 *$ \\
\hline AR90-01-SP & 1 & 276 & $636^{*}$ & 53 & $84 *$ \\
\hline AR03-17-SPF & 4 & 92 & $427 *$ & 17 & $53 *$ \\
\hline AR00-02-SP1 & 2 & 48 & $310 *$ & 10 & $50 *$ \\
\hline $01-118$ & 1 & 622 & $861 *$ & 99 & 99 \\
\hline AR00-05-SP1 & 2 & 56 & $248 *$ & 12 & $56^{*}$ \\
\hline $01-69$ & 1 & 817 & $1,006 *$ & 96 & 100 \\
\hline 2K-129-SP & 1 & 53 & $207^{*}$ & 8 & $41^{*}$ \\
\hline CDL-8-3-SP & 2 & 25 & 95 & 3 & $19 *$ \\
\hline AR03-33-SPF & 3 & 5 & 54 & 1 & $15^{*}$ \\
\hline AR97-01-SP & 3 & 29 & 63 & 4 & 4 \\
\hline AR03-25-SPF & 3 & 17 & 36 & 3 & 6 \\
\hline AR03-31-SPF & 2 & 6 & 22 & $<1$ & 3 \\
\hline AR03-04-SPF & 3 & 17 & 15 & $<1$ & $<1$ \\
\hline CDL-35-3 & 4 & 136 & 87 & 22 & 14 \\
\hline AR03-01-SPF & 4 & 88 & 24 & $16^{*}$ & 2 \\
\hline AR03-14-SPF & 4 & 111 & 32 & 15 & 6 \\
\hline CDL-3-2-SP & 3 & $178 *$ & 40 & $24 *$ & 7 \\
\hline CDL-6-3 & 4 & $164 *$ & 25 & $29^{*}$ & 7 \\
\hline
\end{tabular}

${ }^{\mathrm{w}}$ An asterisk $(*)$ indicates that percentage of spores germinated after $12 \mathrm{~h}$ or AUGC within a row was significantly higher $(P \leq 0.05)$ than the value at the other temperature.

${ }^{x}$ Based on data recorded at 3,6 , and $12 \mathrm{~h}$.

${ }^{\mathrm{y}}$ Based on analysis of arcsine-transformed data.

${ }^{\mathrm{z}}$ Isolates in bold were collected before 2000 and considered "old" and all others were collected since 2000 and considered "new."

Table 7. Means of the latent period, urediniospore germination at $12 \mathrm{~h}$, and area under the germination curve (AUGC) for the four combinations of temperature and isolate group ${ }^{\mathrm{w}}$

\begin{tabular}{lcccc}
\hline Temperature $\left({ }^{\mathbf{}} \mathbf{C}\right)$ & Group $^{\mathbf{x}}$ & Latent period (days) & ${\text { Germination at 12 h }(\%)^{\mathbf{y}}}$ & AUGC $^{\mathbf{z}}$ \\
\hline 12 & Old & $11.8 \mathrm{a}$ & $19.6 \mathrm{~b}$ & $135 \mathrm{~b}$ \\
12 & New & $11.5 \mathrm{a}$ & $19.2 \mathrm{~b}$ & $156 \mathrm{~b}$ \\
18 & Old & $11.9 \mathrm{a}$ & $19.3 \mathrm{~b}$ & $157 \mathrm{~b}$ \\
18 & New & $9.8 \mathrm{~b}$ & $41.1 \mathrm{a}$ & $318 \mathrm{a}$ \\
\hline
\end{tabular}

${ }^{\text {w } M e a n s ~ w i t h i n ~ a ~ c o l u m n ~ f o l l o w e d ~ b y ~ t h e ~ s a m e ~ l e t t e r ~ a r e ~ n o t ~ s i g n i f i c a n t l y ~ d i f f e r e n t ~ a c c o r d i n g ~ t o ~ p a i r-~}$ wise $t$ tests $(P \leq 0.05)$.

${ }^{x}$ Old isolates were collected before 2000 and new isolates were collected since 2000.

${ }^{y}$ Based on analysis of arcsine-transformed data.

${ }^{\mathrm{z}}$ Based on data collected at 3, 6, and $12 \mathrm{~h}$. 
type higher than that conferred by $\operatorname{Yr} 9$ alone, and this may allow initial spore production to occur normally on primary leaves of seedlings even though the hostpathogen interaction is classified as resistant.

All of the new races in this study appear to have virulence genes that are unnecessary for attacking cultivars in states east of the Rocky Mountains. Virulence for the differential lines Express, Compair, and Avocet isoline $\mathrm{Yr} 8$ should confer no selective advantage because the resistance genes in these lines are unlikely to be in cultivars that are grown in the region. Also, many of the new races are virulent on 9 to 13 of the 20 differential lines (4; U.S. Stripe Rust Survey results 2001 to 2004, X. M. Chen, personal communication). According to the concept of stabilizing selection that first was proposed by Vanderplank (24), races with unnecessary virulence should have lower fitness and be less competitive than races with only necessary virulence. Stabilizing selection does not appear to function in $P$. striiformis $\mathrm{f}$. sp. tritici because several races with unnecessary virulence genes have been found at high frequencies across several regions (4; U.S. Stripe Rust Survey results 2001 to 2004, X. M. Chen, personal communication). High levels of aggressiveness in races that have unnecessary virulence, as reported in this study, may explain why stabilizing selection does not work and indicates that some unnecessary virulence genes may be linked to genes for high aggressiveness. Because the pathogen appears to be able to accumulate several unnecessary virulence genes in a genotype and still maintain high levels of aggressiveness, pyramiding major resistance genes or deploying them in multiline cultivars may not be highly effective for the management of stripe rust.

Similarly, Osoro and Green (19) concluded that stabilizing selection did not exist for $P$. graminis f. sp. tritici (the cause of wheat stem rust). They found that races with a greater number of unnecessary virulence genes were more aggressive than races with a lesser number of unnecessary virulence genes. Furthermore, they found that certain races were better adapted to cause disease at either cooler or warmer temperatures than other races. Katsuya and Green (13) also reported that differences in aggressiveness of $P$. graminis f. sp. tritici races, measured by latent period and spore production at different temperatures, determined which race predominated when races were mixed and cycled for several generations at different temperatures.

An additional factor that may be contributing to the fitness of new isolates in the south-central United States is an enhanced ability to survive over summer when it has been considered too hot for $P$. striiformis. Enjalbert et al. (7) determined that the population of $P$. striiformis $\mathrm{f}$. sp. tritici in southern France is adapted to the Mediterranean region and hypothesized that this population may be more fit than the population from northern France to survive over summer in the region. They further hypothesized that the ability to reproduce on wild grass species in the region may be a likely mechanism for enhanced oversummering.

\section{ACKNOWLEDGMENTS}

We thank X. M. Chen for providing isolates, race identifications, and results of annual race surveys; Y. Wamishe for obtaining some of the single-pustule isolates; E. Sanders of the Southern Regional Climate Center for providing summarized weather data; S. Markell and P. Rohman for technical assistance; M. Milus for manuscript preparation; and the Arkansas Wheat Promotion Board for financial support.

\section{LITERATURE CITED}

1. Andrivon, D. 1993. Nomenclature for pathogenicity and virulence: the need for precision. Phytopathology 83:889-890.

2. Anonymous. 2000-2005. Cereal Rust Bulletins, 2000-2005. USDA, ARS Cereal Disease Laboratory, St. Paul, MN. Published online.

3. Carleton, M. A. 1915. A serious new wheat rust in this country. Science 42:58-59.

4. Chen, X. M., Moore, M., Milus, E. A., Long, D. L., Line, R. F., Marshall, D., and Jackson, L. 2002. Wheat stripe rust epidemics and races of Puccinia striiformis f. sp. tritici in the United States in 2000. Plant. Dis. 86:39-46.

5. de Vallavieille-Pope, C., Huber, L., Leconte, M., and Goyeau, H. 1995. Comparative effects of temperature and interrupted wet periods on germination, penetration and infection of Puccinia recondita $\mathrm{f}$. sp. tritici and $P$. striiformis on wheat seedlings. Phytopathology 85:409415 .

6. Emge, R. G. 1963. Technique for germinating uredospores of Puccinia striiformis. (Abstr.) Phytopathology 53:745.

7. Enjalbert, J., Duan, X., Leconte, M, Hovmoller, M. S., and de Vallavieille-Pope, C. 2005. Genetic evidence of local adaptation of wheat yellow rust (Puccinia striiformis $\mathrm{f}$. sp. tritici) within France. Mol. Ecol. 14:20652073.
8. Futrell, M. C., Atkins, I. M., and Hobbs, C. D. 1959. Unusual occurrence of small-grain diseases in Texas in 1957 and 1958. Plant Dis. Rep. 43:777-781.

9. Futrell, M. C., Lahr, K. A., Porter, K. B., and Atkins, I. M. 1959. Second stripe rust epiphytotic in Texas hits wheat crop in 1958. Plant Dis. Rep. 43:165-167.

10. Humphrey, H. B. 1941. Brief notes on plant diseases. Plant Dis. Rep. 25:337-338.

11. Humphrey, H. B., Hungerford, C. W., and Johnson, A. G. 1924. Stripe rust (Puccinia glumarum) of cereals and grasses in the United States. J. Agric. Res. 19:257-278.

12. Johnson, R., and Taylor, A. J. 1972. Isolates of Puccinia striiformis collected in England from the wheat varieties Maris Beacon and Joss Cambier. Nature 238:105-106.

13. Katsuya, K., and Green, G. J. 1967. Reproductive potentials of races $15 \mathrm{~B}$ and 56 of wheat stem rust. Can. J. Bot. 45:1077-1091.

14. Lehman, J. S., and Shaner, G. 1996. Genetic variation in latent period among isolates of Puccinia recondita f. sp. tritici on partially resistant wheat cultivars. Phytopathology 86:633-641.

15. Line, R. F. 2002. Stripe rust of wheat and barley in North America: A retrospective historical review. Annu. Rev. Phytopathol. 40:75118.

16. Line, R. F., and Qayoum, A. 1991. Virulence, aggressiveness, evolution, and distribution of races of Puccinia striiformis (the cause of stripe rust of wheat) in North America. 196887. U. S. Dep. Agric. Agric. Res. Serv. Tech. Bull. 1788.

17. Manners, J. G. 1950. Studies on the physiologic specialization of yellow rust (Puccinia glumarum [Schm.] Erikss. \& Henn.) in Great Britain. Ann. Appl. Biol. 37:187-214.

18. Milus, E. A., and Seyran, E. 2004. New races of Puccinia striiformis f. sp. tritici more aggressive than older races at $18^{\circ} \mathrm{C}$. Page A2.50 in: Proc. 11th Int. Cereal Rusts and Powdery Mildews Conf., Norwich, UK.

19. Osoro, O. M., and Green, G. J. 1976. Stabilizing selection in Puccinia graminis tritici in Canada. Can. J. Bot. 54:2204-2214.

20. Priestly, R. H., and Doling, D. A. 1974. Aggressiveness of Puccinia striiformis isolates on wheat cultivars. Trans. Br. Mycol. 63:549-557.

21. Rapilly, F. 1979. Yellow rust epidemiology. Annu. Rev. Phytopathol. 17:59-73.

22. Seyran, E., and Milus, E. A. 2004. Isolate by temperature interaction for aggressiveness among isolates of Puccinia striiformis f. sp. tritici. (Abstr.) Phytopathology 94:S95.

23. Shaner, G., and Powelson, R. L. 1971. Epidemiology of stripe rust of wheat, 1961-1968 Oreg. Agric. Exp. Stn. Tech. Bull. No. 117

24. Van der Plank, J. E. 1963. Plant Diseases: Epidemics and Control. Academic Press, New York.

25. Volin, R. B., and Sharp, E. L. 1973. Physiologic specialization and pathogen aggressiveness in stripe rust. Phytopathology 63:699-703.

26. Zadoks, J. C. 1961. Yellow rust on wheat: studies in epidemiology and physiologic specialization. Tijdschr. Planteziekten 67:69-259. 